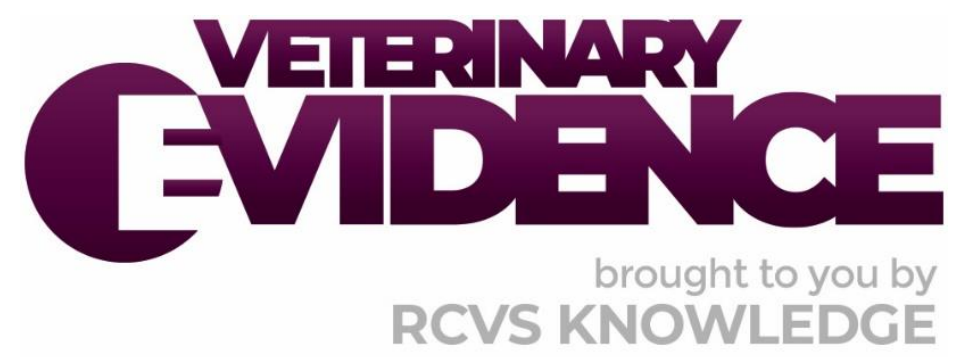

\title{
Thrombolytic Therapy in the Acute Period of Aortic Thromboembolism in Cats
}

\author{
A Knowledge Summary by \\ Joshua Billy Hannabuss BVetMed, PGDipVCP, MRCVS ${ }^{*}$ \\ ${ }^{1}$ University of Bristol, Bristol Veterinary School, Langford House, Langford, Bristol BS40 5DU
${ }^{*}$ Corresponding Author (jhannabuss@rvc.ac.uk)
}

ISSN: 2396-9776

Published: 06 Jun 2019

in: Vol 4, Issue 2

DOI: http://dx.doi.org/10.18849/ve.v4i2.212

Reviewed by: Theodora Tsouloufi (DVM, PhD, MRCVS) and Melanie Hezzell (MA(Cantab.), VetMB(Cantab.), PhD(RVC), CertVDI, CertVC, MRCVS, DACVIM)

Next Review Date: 20 Jan 2020 
KNOWLEDGE SUMMARY

\section{PICO question}

Of cats that present with aortic thromboembolism, do patients that receive thrombolytic therapy in the acute phase have improved survival as compared to those who do not?

\section{Clinical bottom line}

Based on the current available evidence, the use of thrombolytic therapy in the acute phase of aortic thromboembolism (ATE) does not appear to improve survival when compared to conventional supportive therapy. Frequently reported adverse side effects further questions its merits, and large scale controlled clinical trials would be required to further evaluate any benefit in the use of this therapy.

\section{Clinical Scenario}

An 8-year-old male neutered domestic shorthair presents with acute onset bilateral hindlimb paralysis. On auscultation, a grade III/VI heart murmur is detected. Femoral pulses are absent, distal hindlimbs are cool when palpated and the hindlimb paw pads appear cyanotic. A previous diagnosis of pre-clinical hypertrophic cardiomyopathy had been confirmed on echocardiography. You are strongly suspicious of an aortic thromboembolism and the owner is keen to pursue further treatment. A repeat echocardiogram reveals enlargement of the left atrium, with atrial smoke but no visible thrombus. A quick TFAST is absent for B-lines which may reflect left sided congestive heart failure (CHF).

In addition to supportive therapy, would additional thrombolytic treatment for clot dissolution improve outcome in the acute phase?

\section{The evidence}

Six studies were included that best answered the proposed PICO question. A number of thrombolytic therapies have been described for aortic thrombosis, however a lack of controlled studies prohibits direct comparison between those that receive conventional supportive therapy and the different thrombolytic options.

Three of the six studies were included for survival statistics of cats that did not receive a form of thrombolytic therapy and the three studies evaluating thrombolytic therapy explored the use of streptokinase, rheolytic thrombectomy and tissue plasminogen activator (tPA).

The three studies included for the survival statistics were all retrospective case series ranking low in evidence hierarchy. 


\section{Summary of the evidence}

\begin{tabular}{|c|c|}
\hline \multicolumn{2}{|l|}{ Schoeman, J.P. (1999) } \\
\hline Population: & $\begin{array}{l}\text { - Cats presenting to a first opinion veterinary hospital over an } \\
8 \text { year period with clinical signs of distal aortic } \\
\text { thromboembolism } \\
\text { - Episodes classified as: } \\
\text { O Complete } 34 / 49(69 \%) \text { : absent bilateral femoral } \\
\text { pulses; cold limbs; cyanosis of the nailbeds and } \\
\text { hindlimb paralysis } \\
\text { Partial } 19 / 49 \text { (39\%): reduced femoral pulses; } \\
\text { proprioceptive deficits and unilateral or bilateral } \\
\text { hindlimb paresis }\end{array}$ \\
\hline Sample size: & 44 cats (49 episodes of ATE) \\
\hline Intervention details: & 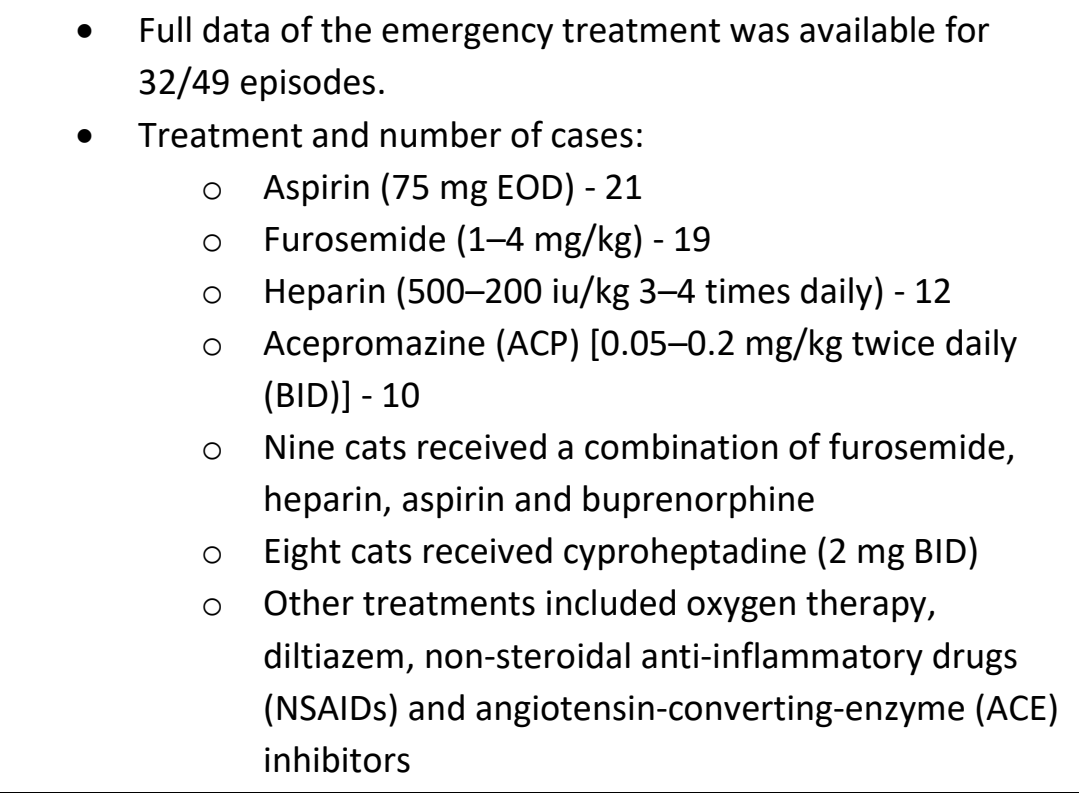 \\
\hline Study design: & Retrospective case series \\
\hline Outcome studied: & $\begin{array}{l}\text { Evaluation of records of cats presenting to a first opinion veterinary } \\
\text { hospital with clinical signs of distal aortic thromboembolism. }\end{array}$ \\
\hline Main findings: & $\begin{array}{l}\text { - Overall, cats survived } 39 \% \text { (19/49) of the episodes } \\
\circ \text { Cats survived } 93 \% \text { (14/15) of the partial episodes } \\
\circ \quad \text { Cats survived } 15 \%(5 / 34) \text { of the complete episodes } \\
\text { - Similar to other studies, ATE seemed associated with } \\
\text { decompensation of pre-existing heart disease }\end{array}$ \\
\hline
\end{tabular}




\begin{tabular}{|c|c|}
\hline Limitations: & $\begin{array}{l}\text { - Retrospective - diagnostics, treatment and population not } \\
\text { standardised } \\
\text { - Complete emergency data was only available for } 32 \text { of the } \\
\text { cases } \\
\text { - Limb assessment subjective } \\
\text { - Diagnosis of heart failure questionable from available } \\
\text { - Each episode of ATE survived was included in the overall } \\
\text { survival figure. This means a single cat surviving multiple } \\
\text { episodes could skew the result of the overall population. } \\
\text { ATE severity and prognosis is dependent on multiple factors } \\
\text { which include episode severity, treatments provided and co- } \\
\text { morbidity. These factors should be considered in individuals } \\
\text { that went on to survive multiple episodes } \\
\text { - Incomplete records }\end{array}$ \\
\hline
\end{tabular}

Moore, K.E. et al. (2000)

\begin{tabular}{|c|c|}
\hline Population: & $\begin{array}{l}\text { - Cats with clinical signs of ATE presenting to two } \\
\text { hospitals between 1992-1998 (one university) treated } \\
\text { with streptokinase (SK) } \\
\text { O Definition: dysfunction in one or two limbs and } \\
\text { lack of arterial pulse in affected limb } \\
\text { - Limbs affected: } \\
\quad 0 \quad 89 \% \text { hindlimb paresis or paralysis } \\
\circ 9 \% \text { monoparesis hindlimb } \\
\circ 2 \% \text { monoparesis forelimb } \\
\text { - } 33 / 43(77 \% \text { ) cats presented hypothermic ( } 43 / 46 \text { had } \\
\text { temperature recorded) } \\
\text { - 21/32 (66\%) were in CHF ( } 32 / 46 \text { cats had thoracic } \\
\text { radiographs on admission) } \\
\text { - 36/36 (100\%) had echocardiographic evidence of structural } \\
\text { heart disease (echocardiography was performed on 36/46 } \\
\text { cats) }\end{array}$ \\
\hline Sample size: & 46 cats \\
\hline Intervention details: & $\begin{array}{l}\text { - Streptokinase dosed on } \mathrm{u} / \mathrm{kg} \text { basis } \\
\text { - Duration of infusion ranged from 1-28 hours (median } 4 \\
\text { hours) } \\
\text { - } 35 \%(16 / 46) \text { cats received ACP } \\
\text { - Cats also received nitroglycerin (dose not stated), heparin } \\
\text { (50-232 u/kg four times daily (QID) subcutaneous (S/C)) and } \\
\text { other unspecified therapies }\end{array}$ \\
\hline Study design: & Retrospective case series \\
\hline
\end{tabular}




\begin{tabular}{|c|c|}
\hline Outcome studied: & $\begin{array}{l}\text { - To identify complications and outcomes of cats treated } \\
\text { with SK following ATE } \\
\text { - Whether time administered following clinical signs } \\
\text { altered outcome } \\
\text { - Prognostic indicators }\end{array}$ \\
\hline Main findings: & $\begin{array}{l}\text { - } 18 / 46(39 \%) \text { died in hospital } \\
\text { - } 13 / 46(28 \%) \text { were euthanised due to poor response to } \\
\text { treatment or complications } \\
\text { - } 15 / 46(33 \%) \text { were discharged } \\
\text { - } 25 / 46(54 \%) \text { regained arterial pulses within } 2-24 \text { hours } \\
\text { post streptokinase } \\
\text { - } 14 / 46(30 \%) \text { regained motor function } \\
\text { - } 18 / 46(39 \%) \text { developed evidence of clinical bleeding or } \\
\text { had measurable coagulation abnormalities following SK } \\
\text { - Higher rectal temperature was associated with survivors } \\
\text { - No significant difference between survivors and } \\
\text { nonsurvivors and time of SK administration } \\
\text { - Hyperkalaemia post SK administration (40/46 had serum } \\
\text { potassium levels measured following SK administration): } \\
\circ \quad 14 / 40 \text { (35\%) of cats } \\
\text { Two suspected based on electrocardiogram (ECG) } \\
\text { changes } \\
\text { - } 11 / 16 \text { (69\%) of these cats died in hospital, four were } \\
\text { euthanised and one discharged. } \\
\text { Cats who received heparin were more likely to survive (P = } \\
\text { 0.052) }\end{array}$ \\
\hline Limitations: & $\begin{array}{l}\text { - Retrospective: sample population; treatment and } \\
\text { diagnostics performed were not standardised } \\
\text { - Incomplete clinical records } \\
\text { - No control group } \\
\text { - Highly variable range in administration time of SK }\end{array}$ \\
\hline
\end{tabular}

Smith, S.A. et al. (2003)

Population:

- Cats presenting to the University of Minnesota Veterinary hospital over a 10 year period with clinical signs of ATE

- Cats with clinical signs $>2$ days were excluded

- Limbs affected:

○ $72 \%$ bilateral hindlimbs

- $2 \%$ bilateral hindlimb and one forelimb

- $13 \%$ one hindlimb

- $12 \%$ one forelimb

- $2 \%$ other body system affected

- $55 / 125$ (44\%) had CHF on presentation (125/250 had thoracic radiographs or post-mortem) 


\begin{tabular}{|c|c|}
\hline & $\begin{array}{l}\text { - } 72 / 110(65 \%) \text { presented hypothermic }(110 / 250 \text { had records } \\
\text { of rectal temperature) }\end{array}$ \\
\hline Sample size: & 127 cats \\
\hline Intervention details: & $\begin{array}{l}\text { - Supportive therapy: } \mathrm{n} 41 \text { - fluid therapy; heat - n24; physical } \\
\text { therapy - n14; oxygen - } \mathrm{n} 34 \text {; analgesia - n53 } \\
\text { - Streptokinase infusion (dose not stated): } \mathrm{n} 4 \\
\text { - Anticoagulant therapy: unfractionated heparin ( } 75-500 \mathrm{u} / \mathrm{kg} \\
\mathrm{I} / \mathrm{V} \text { single dose; } 10-300 \mathrm{u} / \mathrm{kg} \mathrm{S/C} \mathrm{q6-12} \mathrm{hours)} \mathrm{-} \mathrm{n67;} \mathrm{aspirin} \\
\text { - n46 } \\
\text { - Aspirin dose: } \\
\circ \text { High (HDA) } \geq 40 \mathrm{mg} / \text { cat } \mathrm{q} 72 \mathrm{~h}-\mathrm{n} 35 \text { ( } 27 \text { in } \\
\text { conjunction with heparin) } \\
\text { Low (LDA) } 5 \mathrm{mg} / \text { cat } \mathrm{q} 72 \mathrm{~h}-\mathrm{n} 12 \text { (six in conjunction } \\
\text { with heparin) }\end{array}$ \\
\hline Study design: & Retrospective case series \\
\hline Outcome studied: & $\begin{array}{l}\text { Do clinical findings of acute ATE provide prognostic } \\
\text { information? } \\
\text { - Can survival curves be created for cats that survive the initial } \\
\text { episode? } \\
\text { - To compare the use of low dose and high dose aspirin in cats } \\
\text { surviving the initial episode }\end{array}$ \\
\hline Main findings: & 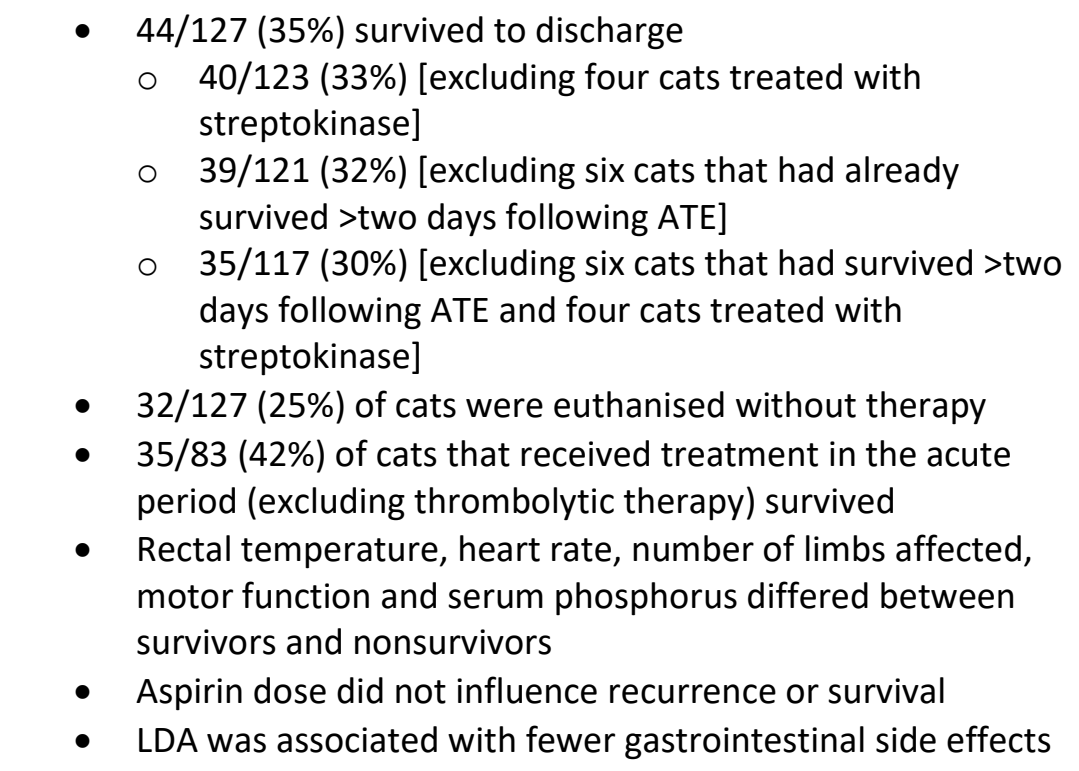 \\
\hline Limitations: & $\begin{array}{l}\text { - Retrospective - diagnosis, treatment and patient cohort was } \\
\text { not standardised } \\
\text { - The study might be underpowered for comparison of aspirin } \\
\text { doses } \\
\text { - } 10 \text { year study. Earlier data demonstrated poorer survival } \\
\text { which skews overall statistics } \\
\text { - There is limited discussion of supportive therapy. Fluid } \\
\text { therapy may be detrimental in CHF cases }\end{array}$ \\
\hline
\end{tabular}




\begin{tabular}{|c|c|}
\hline \multicolumn{2}{|l|}{ Reimer, S.B. et al. (2006) } \\
\hline Population: & $\begin{array}{l}\text { - Cats presenting to the University of California veterinary } \\
\text { hospital with bilateral paralysis in pelvic limbs caused by } \\
\text { aortic thromboembolism } \\
\text { - Cats with palpable femoral pulses were excluded } \\
\text { - All cats presented hypothermic } \\
\text { - All cats had underlying myocardial disease } \\
\text { - Mean time between onset of clinical signs and } \\
\text { thrombectomy was } 44.8 \text { hours (+/- 72.6h) range 5-192 } \\
\text { hours }\end{array}$ \\
\hline Sample size: & Six cats \\
\hline Intervention details: & $\begin{array}{l}\text { - Heparin pretreatment (150 iu/kg) S/C to prevent additional } \\
\text { thromboembolic events during vascular manipulation. This } \\
\text { was continued q6h postoperative, for the next } 24 \text { hours } \\
\text { - Standardised AngioJet }{ }^{\mathrm{TM}} \text { rheolytic thrombectomy system via } \\
\text { carotid artery } \\
\text { - Enoxaparin sodium ( } 1 \mathrm{mg} / \mathrm{kg} \mathrm{S/C} \mathrm{BID)} \mathrm{started} 24 \text { hours } \\
\text { postoperative } \\
\text { - Streptokinase ( } 45,000 \mathrm{iu} \text { ) was delivered locally in one patient } \\
\text { due to unsuccessful thrombectomy }\end{array}$ \\
\hline Study design: & Prospective clinical trial (nonrandomised, nonblinded) \\
\hline Outcome studied: & $\begin{array}{l}\text { To determine the safety and efficacy of the AngioJet }{ }^{T M} \text { rheolytic } \\
\text { thrombectomy system in the treatment of ATE }\end{array}$ \\
\hline Main findings: & $\begin{array}{l}\text { - } 5 / 6(83 \%) \text { of cats had clot dissolution } \\
\text { - } 1 / 6(17 \%) \text { died of uncontrollable hypotension and cardiac } \\
\text { arrest } \\
\text { - } 2 / 6(33 \%) \text { were euthanised, one following streptokinase } \\
\text { administration due to severe hypotension and extravasation } \\
\text { from the aorta and the other } 12 \text { hours post-op due to } \\
\text { progressive acidaemia and hyoptenstion } \\
\text { - } 3 / 6(50 \%) \text { were discharged from hospital with varying } \\
\text { degrees of ambulatory deficits but all had palpable femoral } \\
\text { pulses } \\
\text { The time between clinical signs and thrombectomy was not } \\
\text { a predictor of outcome }\end{array}$ \\
\hline Limitations: & $\begin{array}{l}\text { - Small cohort } \\
\text { - No control group } \\
\text { - } \text { Concurrent therapy of heparin and enoxapram } \\
\text { - } \text { One cat received streptokinase due to unsuccessful } \\
\text { - } \quad \text { Some patients already survived up to } 192 \text { hours } \\
\text { - It is likely that the study is underpowered from the small }\end{array}$ \\
\hline
\end{tabular}


Welch, K.M. et al. (2010)

\begin{tabular}{|c|c|}
\hline Population: & $\begin{array}{l}\text { - Cats presenting with clinical signs of ATE to Tufts University } \\
\text { - } \quad \text { Limbs affected: } \\
\quad \quad 91 \% \text { bilateral pelvic limbs } \\
0 \quad 9 \% \text { unilateral forelimb } \\
\text { - } \quad 8 / 11(73 \%) \text { of cats were hypothermic on presentation } \\
\text { - } \quad 1 / 11(9 \%) \text { cat was diagnosed with previous heart disease } \\
\text { - } \quad 9 / 11(82 \%) \text { cats had at least one or more limbs with absent } \\
\text { - } \quad \text { pulses and motor function at admission } \\
\text { 3/11 (27\%) cats had motor function in one or more affected } \\
\text { limbs prior to tPA administration }\end{array}$ \\
\hline Sample size: & 11 cats \\
\hline Intervention details: & $\begin{array}{l}\text { - Group A ( } 7 \text { cats) Tissue plasminogen activator (tPA) } \\
\text { continuous rate infusion (CRI) over } 4 \text { hours totalling } 5 \mathrm{mg} \\
\text { tPA per cat } \\
\text { - Group B ( } 4 \text { cats) Tissue plasminogen activator accelerated } \\
\text { protocol: } 1 \mathrm{mg} \text { IV bolus followed by } 2.5 \mathrm{mg} \text { over } 30 \text { mins and } \\
\text { then } 1.5 \mathrm{mg} \text { over } 1 \text { hour } \\
\text { - Additional } 5 \mathrm{mg} \text { CRI over } 4 \text { hours if unresponsive (two cats in } \\
\text { both groups) }\end{array}$ \\
\hline Study design: & Prospective randomised clinical trial (nonblinded) \\
\hline Outcome studied: & $\begin{array}{l}\text { - To compare two different dosing strategies of tPA } \\
\text { - To determine side effects } \\
\text { - Assess treatment response through pulse and motor } \\
\text { function }\end{array}$ \\
\hline Main findings: & $\begin{array}{l}\text { - } 7 / 11(64 \%) \text { of cats survived } 24 \text { hours } \\
\text { - } \quad 4 / 7(57 \%) \text { had motor function at } 24 \text { hours } \\
\text { - } \quad 3 / 11(27 \%) \text { survived to discharge } \\
\text { - } 6 / 9(67 \%) \text { cats had return of pulses or improved limb scores } \\
12 \text { hours post drug administration (these nine cats had at } \\
\text { least one or more limbs with absent pulses and motor } \\
\text { function at admission) } \\
\text { - } \text { Adverse side effects in all patients led to early termination } \\
\text { of the study. The reported adverse side effects were: } \\
\text { arrhythmias; azotemia; hyperkalaemia; neurological signs } \\
\text { with respiratory arrest in three cases; cardiac arrest and } \\
\text { haemorrhage in one cat. There was no difference in }\end{array}$ \\
\hline
\end{tabular}




\begin{tabular}{|c|c|}
\hline & outcome between clinical signs and therapy initiation \\
\hline Limitations: & 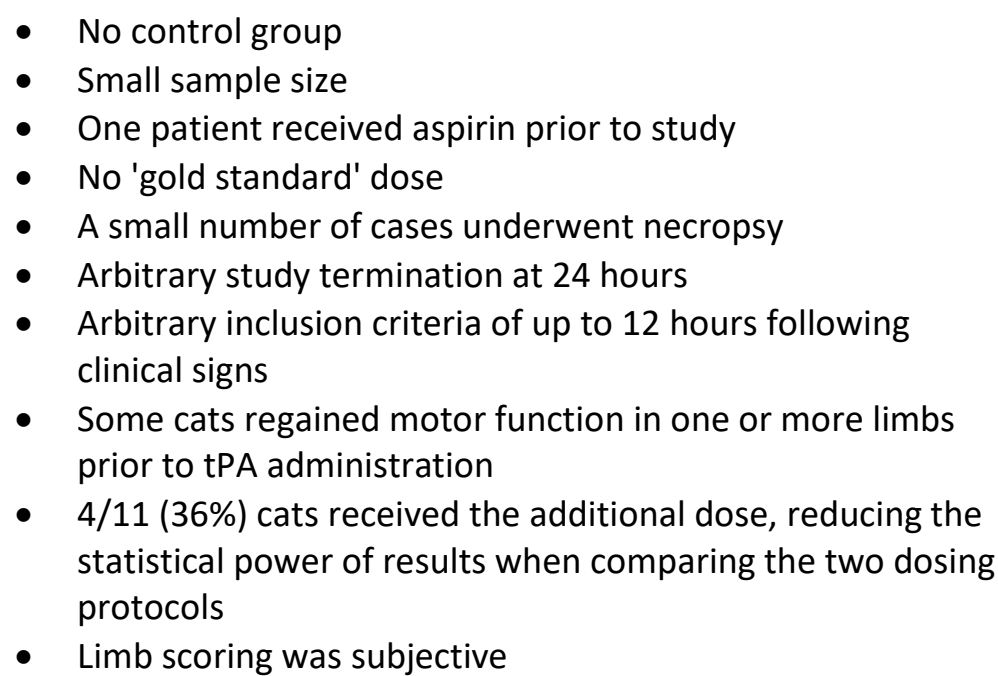 \\
\hline
\end{tabular}

Borgeat, K. et al. (2014)

\begin{tabular}{|c|c|}
\hline Population: & $\begin{array}{l}\text { - Cats presenting to three practices over a } 98 \text { month period } \\
\text { with clinical signs of arterial thromboembolism } \\
\text { - Limbs affected: } \\
\circ 12 \% \text { unilateral hindlimb } \\
\circ 78 \% \text { bilateral hindlimbs } \\
\circ 9 \% \text { unilateral forelimb } \\
\circ 1 \% \text { of cats had three limbs affected; } \\
\circ \text { one cat had all limbs affected } \\
\text { - Of cats not euthanised at presentation and where evidence } \\
\text { was available, } 42 / 63 \text { (67\%) were in CHF }\end{array}$ \\
\hline Sample size: & 250 cats \\
\hline Intervention details: & $\begin{array}{l}\text { - } 153 / 250 \text { (61\%) were euthanised on presentation } \\
\text { - } \quad \text { Analgesia was provided to all cats not euthanised } \\
\text { - } \text { Diuretic treatment was administered to } 57 / 97 \text { (59\%) cats } \\
\text { - } 68 / 97(70 \%) \text { received combinations of heparin, aspirin and } \\
\text { clopidogrel (doses for treatments not stated) }\end{array}$ \\
\hline Study design: & Retrospective case series \\
\hline Outcome studied: & $\begin{array}{l}\text { - To estimate the prevalence of arterial thromboembolism } \\
\text { (ATE) in cats in the UK presenting to general practice (GP) } \\
\text { - It was hypothesised that for some cats, >one year survival } \\
\text { was possible if they were not euthanised }\end{array}$ \\
\hline Main findings: & $\begin{array}{l}\text { - } 166 / 62856(0.3 \%) \text { prevalence of ATE (practice } 1 \text { and } 3 \text {, data } \\
\text { for total cats visiting practice } 2 \text { was not available) } \\
\text { - } 153 / 250(61 \%) \text { were euthanised at presentation } \\
\text { - } 68 / 250(27 \%) \text { survived the first } 24 \text { hours } \\
\text { - } 30 / 250(12 \%) \text { survived seven days } \\
\text { - } 6 / 250(2 \%) \text { were alive at one year } \\
\text { - } \quad \text { Higher mortality was associated with: } \\
\quad \text { o Lower rectal temperature }\end{array}$ \\
\hline
\end{tabular}




\begin{tabular}{|c|c|}
\hline & $\begin{array}{l}\circ \text { No aspirin/clopidogrel therapy } \\
\circ \text { Management at practice } 2 \text { in the first } 24 \text { hours } \\
\text { - Hypothermia was associated with nonsurvivors }\end{array}$ \\
\hline Limitations: & $\begin{array}{l}\text { - Retrospective - No control over patient population, } \\
\text { diagnostics performed and treatment standardisation } \\
\text { - Small subgroups obscure overall statistics } \\
\text { - } \text { Variable mortality between clinics may reflect case } \\
\text { - } \text { management } \\
\text { - Patabase search terms could be more comprehensive } \\
\text { clinician decision } \\
\text { - Insufficient numbers after seven days weaken significant } \\
\text { predictors of mortality }\end{array}$ \\
\hline
\end{tabular}

\section{Appraisal, application and reflection}

Of the best available evidence, four of the studies were retrospective case series. Three of these studies were included to provide survival information for those that did not receive thrombolytic therapy and the other study explored the use of streptokinase. As retrospective case series, intervention and patient population was not standardised and therefore bias may significantly affect the results. For this reason, direct comparisons cannot be deduced between studies. Of the other two studies which evaluated the use of tPA ( $\mathrm{n}$ $-11)$ and rheolytic thrombectomy $(n-6)$, sample sizes were small and therefore both are likely to be underpowered.

Survival to discharge in patients that did not receive thrombolytic therapy was reported: $33 \%$ (35\% overall survival includes four treated with streptokinase) and $42 \%$ (survivors of the initial event treated with supportive therapy alone in the acute phase) (Smith et al., 2003); 39\% (Schoeman, 1999) and 27\% [first 24 hours], $12 \%$ [at seven days] (Borgeat et al., 2014). Borgeat et al., (2014) reported that $61 \%$ were euthanised at presentation and of the cats that survived the first 24 hours, $47 \%$ were euthanised in the following seven days. Many factors may influence decision making with regards to euthanasia including prognostic indicators (rectal temperature, number of limbs affected, comorbidities, electrolyte parameters etc.) client factors and welfare on an individual basis, which may explain different survival figures between studies.

Reimer, et al. (2006) evaluated the use of rheolytic thrombectomy with a survival of $50 \%$ (three cats). The entire population presented with hindlimb paralysis, absent femoral pulses and hypothermia which has been reported to carry a poor prognosis (Smith et al., 2003; Borgeat et al., 2014). All cats had underlying structural heart disease. Of the $50 \%$ of cats that did not survive to discharge, hypotension was a common clinical finding. Cats also received heparin therapy which has been proposed to influence survival (Moore et al., 2000). Some cats had already survived 192 hours following initial ATE episode so its arguable that these had already survived the acute phase without thrombolytic intervention. The small sample size of this study weakens the statistical power of results.

Moore et al. (2000) reported a survival of $33 \%$ in patients that received streptokinase therapy. $89 \%$ presented with hindlimb paresis/paralysis to which $54 \%$ regained pulses $2-24$ hours following infusion. The incidence of congestive heart failure was $21 / 32(66 \%)$ and of the 36 cats that underwent echocardiography, all cats had evidence of structural heart disease. Infusion time of streptokinase was largely variable (1-28 hours) and other treatment was not standardised with some patients receiving heparin. $35 \%$ of patients were hyperkalaemic post streptokinase therapy which was associated with longer infusion times. Hyperkalaemia is likely a result of reperfusion injury and was negatively associated with survival. Only one cat with documented hyperkalaemia survived to discharge, however six cats did not have serum potassium measured following streptokinase infusion. $39 \%$ of the population developed clinical signs of bleeding or coagulation 
abnormalities and three cats required blood transfusion.

Welch et al. (2010) evaluated the use of two dosing strategies with tissue plasminogen activator (tPA). $64 \%$ of cats survived the initial 24 hours post therapy and $27 \%$ survived to discharge. The study was terminated early due to adverse side effects in all patients. Adverse side effects included: arrhythmias, azotemia, hyperkalemia, neurological signs with respiratory arrest in three cases; cardiac arrest in one cat and haemorrhage. After the first 24 hours, ongoing treatment was at the clinician's discretion and therefore treatment was no longer standardised. A limb scoring system was used to assess pulse and motor quality. Twelve hours post tPA administration, 6/7 (67\%) cats regained pulses or had improvements in limb scores. Smith et al. (2003) has reported a correlation between improving motor function and survival, however many factors could influence this finding including severity of the initial ATE event and the subjectivity of these scoring systems. Similar to the rheolytic thrombectomy study, the sample size was small and therefore statistics are likely to be underpowered.

Decision making with regards to treatment of feline ATE is a multifactorial process that requires careful consideration on a patient by patient basis. This makes it difficult to compare different studies especially those carried out retrospectively. Of the evidence available exploring the use of thrombolytic therapies, sample sizes are small and lack comparative control groups. As discussed, the decision for euthanasia is based on many factors. This should be considered when comparing the survival figures between studies as those investigating the use of thrombolytic therapy represent a population of cats that have been selected for treatment and not euthanised. Although Reimer, et al. (2006) reported a $50 \%$ survival to discharge rate, the significance of this result is questionable by the small sample size and other factors discussed above. The other studies did not demonstrate superior survival compared to conventional supportive therapy. Frequently reported adverse side effects further questions the use of thrombolytic therapy as adjunct treatment.

Ultimately, randomised, large scale controlled clinical trials would be required to see whether there is any merit in the use of thrombolytic therapy in the acute phase of aortic thrombosis.

\title{
Methodology Section
}

\author{
Search Strategy \\ Databases searched and dates CAB Abstracts on OVID platform 1973 to 2017 week 49 \\ covered: MEDLINE on OVID platform 1946 to present \\ Search terms: (cats or cat diseases) OR (cats OR cat OR feline* OR felis) AND \\ (thromboembolism or embolism or thrombosis) OR \\ (arterialthromboembolism or arterial-thromboembolism or \\ thromboembolism or embolism or thrombus)
}

Dates searches performed: CAB Abstracts (20/12/17); Ovid MEDLINE (19/12/17)

\section{Exclusion / Inclusion Criteria}

Exclusion: Papers inappropriate to the PICO (non-related title and abstract; other species; papers unable to demonstrate post therapy outcome) conference proceedings; case reports; non-English language; opinion articles; papers not accessible; experimental ATE; book chapters

Inclusion: Papers identifying acute outcome following use of thrombolytic therapy for ATE; papers with survival statistics for acute period in patients that did not receive thrombolytics (due to lack of comparative studies); naturally occurring ATE; ATE causing limb dysfunction 
Search Outcome

\begin{tabular}{|c|c|c|c|c|c|c|c|c|c|}
\hline Database & $\begin{array}{l}\text { Number } \\
\text { of results }\end{array}$ & $\begin{array}{l}\text { Excluded } \\
\text { - not in } \\
\text { English } \\
\text { language }\end{array}$ & $\begin{array}{l}\text { Excluded - } \\
\text { Non- } \\
\text { relevant to } \\
\text { PICO }\end{array}$ & $\begin{array}{l}\text { Excluded - } \\
\text { Conference } \\
\text { proceedings }\end{array}$ & $\begin{array}{l}\text { Excluded- } \\
\text { book } \\
\text { chapter } \\
\text { etc. }\end{array}$ & $\begin{array}{l}\text { Excluded } \\
\text { - Case } \\
\text { reports }\end{array}$ & $\begin{array}{c}\text { Excluded- } \\
\text { Opinion } \\
\text { article }\end{array}$ & $\begin{array}{l}\text { Excluded- } \\
\text { unable to } \\
\text { access }\end{array}$ & $\begin{array}{c}\text { Total } \\
\text { relevant } \\
\text { papers }\end{array}$ \\
\hline $\begin{array}{c}\text { CAB } \\
\text { abstracts }\end{array}$ & 479 & 105 & 299 & 6 & 49 & 9 & 4 & 1 & 6 \\
\hline Medline & 600 & 101 & 487 & 0 & 0 & 6 & 0 & 1 & 5 \\
\hline \multicolumn{9}{|c|}{ Total papers when duplicates removed: } & 6 \\
\hline
\end{tabular}

\section{CONFLICT OF INTEREST}

The author declares no conflicts of interest.

\section{REFERENCES}

1. Borgeat, K., Wright, J., Garrod, O., Payne, J.R., and Fuentes, V.L. (2014). Arterial thromboembolism in 250 cats in general practice: 2004-2012. Journal of Veterinary Internal Medicine. 28, 102-108.

DOI: https://doi.org/10.1111/jvim.12249

2. Moore, K.E., Morris, N., Murtaugh, R.J., and Rush, J.E. (2000). Retrospective Study of Streptokinase Administration in 46 Cats with Arterial Thromboembolism. Journal of Veterinary Emergency and Critical Care. 10 (4), 245-257. DOI: https://doi.org/10.1111/j.1476-4431.2000.tb00010.x

3. Reimer, S.B., Kittleson, M.D., and Kyles, A.E. (2006). Use of Rheolytic Thrombectomy in the Treatment of Feline Distal Aortic Thromboembolism. Journal of Veterinary Internal Medicine. 20, 290-296. DOI: https://doi.org/10.1111/j.1939-1676.2006.tb02859.x

4. Schoeman, J.P. (1999). Feline distal aortic thromboembolism: a review of 44 cases (19901998). Journal of Feline Medicine and Surgery. 1 (1), 221-231.

DOI: https://doi.org/10.1053/ifms.1999.0049

5. Smith, S.A., Tobias, A.H., Jacob, K.A., Fine, D.M., and Grumbles, P.L. (2003). Arterial Thromboembolism in Cats: Acute Crisis in 127 Cases (1992-2001) and Long-Term Management with Low-Dose Aspirin in 24 Cases. Journal of Veterinary Internal medicine. 17, 73-83. DOI: https://doi.org/10.1111/j.19391676.2003.tb01326.x

6. Welch, K.M., Rozanski, E.A., Freeman, L.M., Rush, J.E. (2010). Prospective evaluation of tissue 
plasminogen activator in 11 cats with arterial thromboembolism. Journal of Feline Medicine and Surgery. 12, 122-128. DOI: https://doi.org/10.1016/i.jfms.2009.08.001 


\section{EVIIDEFeE

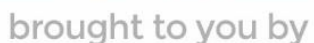 \\ RCVS KNOWLEDGE}

\section{Intellectual Property Rights}

Authors of Knowledge Summaries submitted to RCVS Knowledge for publication will retain copyright in their work, and will be required to grant RCVS Knowledge a non-exclusive license of the rights of copyright in the materials including but not limited to the right to publish, republish, transmit, sell, distribute and otherwise use the materials in all languages and all media throughout the world, and to license or permit others to do so.

\section{Disclaimer}

Knowledge Summaries are a peer-reviewed article type which aims to answer a clinical question based on the best available current evidence. It does not override the responsibility

of the practitioner. Informed decisions should be made by considering such factors as individual clinical expertise and judgement along with patient's circumstances and owners' values. Knowledge Summaries are a resource to help inform and any opinions expressed within the Knowledge Summaries are the author's own and do not necessarily reflect the view of the RCVS Knowledge. Authors are responsible for the accuracy of the content. While the

Editor and Publisher believe that all content herein are in accord with current recommendations and practice at the time of publication, they accept no legal responsibility

for any errors or omissions, and make no warranty, express or implied, with respect to material contained within.

For further information please refer to our Terms of Use.

RCVS Knowledge is the independent charity associated with the Royal College of Veterinary Surgeons (RCVS). Our ambition is to become a global intermediary for evidence based veterinary knowledge by providing access to information

that is of immediate value to practicing veterinary professionals and directly contributes to evidence based clinical decision-making.

\section{https://www.veterinaryevidence.org/}

RCVS Knowledge is a registered Charity No. 230886.

Registered as a Company limited by guarantee in England and Wales No. 598443.

Registered Office: Belgravia House, 62-64 Horseferry Road, London SW1P 2AF

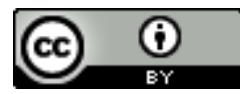

This work is licensed under a Creative Commons Attribution 4.0 International License 